\title{
Legal Enforcement on Environment Pollution in Elegant Gold Mining Activities
}

\author{
Lisda Sy amsumardian \\ Faculty of Law \\ University Pancasila \\ Jakarta, Indonesia \\ lisdazamzam@gmail.com
}

\begin{abstract}
Illegal mining cases in Indonesia, of course, require a law enforcement under applicable legislation to eradicate and provide a deterrent effect against illegal mining actors, in connection with efforts to protect the environment from pollution and destruction caused by illegal mining. Community activities in the fulfillment of life needs are many who ignore the importance of the environment in supporting their lives. Community activities that are very harmful to the current environment that is flourishing in several areas in Indonesia is gold mining. This gold mining is done illegally because it does not have permission from the authorized officials. This mining activity is known as Unlicensed Mining (PETI) gold mining materials. Mining is part of the activities to produce mineral mining and / or coal and minerals related to the mining sector to become the largest foreign exchange earner in Indonesia, but the implementation of the government often faces problems, much Gold mining that occurs in local area land is illegal gold mining that negatively impacts environment, community morality and others. Therefore, it is found that there is uncertainty between the implementation of the regulation and its enforcement, it is necessary from the government to create an Independent Supervisory Team related to the implementation of regulation in mining activities and enforcement, so that the harmony and balance to support sustainable development is implemented with a comprehensive and comprehensive policy and take into account the needs of the generation now and in the future and therefore it is necessary to enforce the law against illegal gold mining activities with certainty and firmly so that illegal mining is not increasingly widespread and can be overcome.
\end{abstract}

Keywords- gold mining, illegal mining, environment

\section{INTRODUCTION}

Since the birth of Law Number 11 Year 1967 on the Provisions of Mining Principles (Mining Law) in the New Order era, has generated a polemic because it is based on the policy of open door politics. It is seen from the number of foreign investors who are interested to invest in the form of Contract of Work (KK), While for the government, this sector is slowly but surely an interesting sector because it has contributed significantly to the State's revenue. On the other side of this sector is very sensitive to create negative excesses for the environment, on the issue then the government submitted a Draft Law on Mineral and Coal (RUUMinerba) in June and then legalized into Law No. 4 of 2009, in the Dealing Law Mining is inseparable from the mandate of the article 33 of the 1945 Constitution[1]. Substitution of mining law is expected by looking at the dynamics of the government system from the central to decentralization, and also the seal of Law issued by Law No. 41 of 2009 on Forestry and Regulation of PP No. 25 of 2000 on the authority of the government and province that gives to the region in managing mineral and rock resources, but this creates mining conditions to be non-conducive, besides through PP Number 25 of 2000, many local governments legalize the existence of PETI (Mining Without Permits) by granting people's mining permits (IPR) this policy is very contrary to the principle of "good minning practies "In which the environment becomes damaged by the possibility of freedom for the people to illegal mining activities.

Comprehensively the Minerba Act No. 4 of 2009 should refer to 4 principles [2] :
a. Benefits, fairness and equilibrium;
b. Partiality to the interests of the nation;
c. Participation, transparency and accountability;
d. Sustainability and environmental insight.

So that article 33 of the 1945 Constitution has been embodied into these principles, which in the pengelolahan mining in a planned and integrate the economic dimension, and environmental and social culture in the overall mining business to realize the present and future prosperity

When viewed from the basic idea of Minerba Law is not separated on the impact of pollution of environmental destruction due to mining activities and various conflicts between communities with mining companies. The commitment of mining activities to environmental protection is a must for every mining business actor through an Environmental Impact Analysis (AMDAL) mechanism.

Theoretically in the preparation of AMDAL must consider various aspects, such as physical, chemical, biological, socioeconomic, social, cultural and public health aspects. A plan of activity can be said not environmentally feasible, if based on the results of AMDAL study the negative impacts can not be overcome available technology. It is clear that the purpose of the AMDAL is to ensure that environmental and socio-economic development considerations of local communities are included in preexploitation[3] , exploitation and post-exploitation plans. Thus, according to the World Bank, AMDAL in mining activities [4].

The affirmation of UUPLH in article 1 point 12 is that environmental management efforts (UKL) and environmental monitoring efforts (UPL) are efforts 
undertaken in environmental management and monitoring by the party responsible for business and / or activities not required to perform AMDAL. Similarly Article 1 point 11, UUPLH attached to the attachment of the State Minister of Environment Regulation Number 11 of 2006 requires that AMDAL be made based on the mining area, which is more than 200 ha shall be required to make AMDAL. This provision means that mining areas (IUP and IUKP) of less than 200 are not mandatory AMDAL but the company concerned must prepare UKL and IPL as stipulated in Article 2.

\section{PROBLEM}

Questioning the difficult problem to be solved in Indonesia in mining business activity is illegal gold mining, one of which is in aceh area recently arrested illegal gold mining activity in aceh forest. PETI is an activity of Unlicensed Gold Mining which is done by some people and other elements. PETI ("Unlicensed Gold Mining") is a "stamp" given by the State to mining actors who are not licensed by the government as holders of state control over mining materials. Regardless of whether mining is the people doing mining activities based on customs, or those who only "gamble" the fate of minerals, it will still hold the label PETI if it is not licensed, Considering PETI activities that do not apply the rules of mining properly (good min ing practice and almost untouchable, while on the other hand non-renewable materials (nonrenewable resources) and in its potentially destructive environment (poll poll), then what happens then are the negative impacts that not only harm the Government, but also the wider community and future generations. Environmental damage, waste of mineral resources, and moral decline are examples of negative impacts that are detrimental to the Government, the wider community and future generations.

Enforcement in case of illegal mining in Aceh city During the period of 2017-2018, 10 people have been designated as suspects in illegal gold mining case in Aceh. Currently, they are currently undergoing trials. While 4 suspects are still in the process of investigation and detained in Mapolda Aceh. The Directorate of Special Criminal Investigation (Ditkrimsus) of the Aceh Police has arrested four suspected illegal miners and 5 heavy equipment (excavators) seized. The four suspects are the owners and supervisors of the heavy equipment that illegally mining in protected forests and production. The four suspects were charged with article 158 Jo article 37 of Law No. 4 of 2009 on mineral and coal mining. They are also charged with article 89 paragraph (1) sub-paragraph b of Law No. 18 of 2013 on Prevention and Eradication of Forest Destruction with threats ranging from 6-10 years in pris on and a fine of Rp 10 billion.

When viewed from the above problems as to where law enforcement for the miners without this permit, the government or apparatus has been properly implemented as regulated in the Act. In the PETI need to note things that encourage, among others, Characteristics of mining business Mining business in general provides relatively high material benefits, because some minerals without through direct processing can be sold. Demand for the relatively high quarrying market, especially in areas with high physical development growth. Easy level of cultivation, especially for minerals class C. Very short mining period, some of which are shorter than the length of the licensing process, because most of them are small scale mining. Local government unpreparedness A complicated and time-consuming process of licensing The occurrence of bribery and extortion practices that lead to retribution and taxes do not reach the government's treasury, Weak supervision of mining operations, and Weak law enforcement.

\section{ANALYSIS AND FINDINGS}

In the findings of this paper the issue of enforcement is the main factor, the intention of the central and regional governments must synergize, in the application of regulations and enforcement should the government should put aside some factors that will make law enforcement constraints, such as economic problems, boost the per capita income of the population, may still be a factor in the development of illegal mining practices.

If the choice of the concept of state control over mining is based on the theory of sovereignty or souverenniteit, according to van Vollenhoven where the State has the power to enact legislation in regulating all things with authority, see from this van Vollenhoven opinion, as central and local government must have a definite intent and purpose, must put aside his political interests, together realize the populist economy based on Pancasila certainly consider the aspect of environment and sustainable development.

Often, however, many argue that more State involvement and intervention will reap problems, as the State's interference will lead to "Inefficiency" in the allocation of capital and employment, this condition will be increasingly unclear if it is not supported by adequate socio-political stability. In this case, to realize the condition, it is necessary to prerequisite a strong and neutral state, because the State will become the central of the problems related to natural resources [5].

Along with the control of the State should at least address the "pro-people" policy, the meaning of the Minerba Act specifically regulates the aspects of community involvement around the WP, should be in the formulation of regional regulations on min ing, local government should pay attention to the socio-cultural aspects of local communities, sociolocal needs to be addressed are those that relate to natural resource access including WIRP must be open and give priority to the communities living around the WIRP first.

It can be concluded, in legal theory, to distinguish between the responsibility of the meaning of "liability" and the responsibility in the meaning of "responsibility" with the argument that the area of moral rights is relatively unlike the territory of legal rights, because morals and laws are gradual. Moral norms are the rule of human attitudes as the subject of law, which deals with the rules of good bad, justly unjust actions of human behavior. While the norm of law is the formulation and legitimacy of the moral norms or moral values themselves. As a rule the norm reflects the expectations, wishes and beliefs of all members of society about how life is the formulation and legitimacy of moral norms or moral values themselves. As a rule, the legal norms reflect the expectations, wishes and beliefs of all me mbers of society about how to live well in society [6].

Moral norms are not poured in written or undocumented form, whereas legal norms are the moral norms that have been privatized [7] 
From the findings of some PETI cases occurring in Indonesian territory and enforcement is sues in environmental pollution. The state in a dilemma position, which has the right to control natural resources for the welfare of the Indonesian people to prosper and prosper, but still exercising the right to enforce the law of the rule for the sake of the nation and the sustainability of development.

Then it should be rules related to the mining business and permission must be accounted for publicly. But nowadays, more and more companies and private organizations are recognized and acknowledged as institutions that have power over the power of the State, so it should be a democratic country listening to the aspirations of society for the sake of national interests, the State and the government must have independent supervis ory institutions of some stakeholders of national and private mining activities, to synergize to provide oversight and assist in enforcement process in illegal mining business activities. Because in regulation regulations, permits, can already reflect the principles and norms of justice, but how enforcement and implementation in the field, it is definitely starting from the morals and intentions of central and local government officials in preserving the natural wealth of Indonesia that can be fully utilized for the welfare of the people Indonesia, as stipulated in Article 33UUD NRI 1945.

Indonesian society is accustomed to being a society that already has very rich natural resources, so sometimes their principle can actually harm their own, by always continuously in solving problems and work assisted by foreign professional workers and cooperate with foreign companies, so the involvement of cooperation in mining activities by Indonesia and foreign parties are a dilemma and are overshadowed by unlimited cooperation, such as mining activities in Freeport, linked to the enforcement process in preserving the environment before and after mining activities. Therefore, in law enforcement can not only see from the sanction only, but must have SOP or operational standard related to mining activities from exploration to exploitation, that is by putting responsibility and owning for the local community in its mining area.
From the conclusion in this writing, the author, will give a recommendation that mining activities can not be separated from the manipulation of law and power considering the problem of mining is a national problem of central and regional, but we can sikapi by civilizing the coordination system on several stakeholders independece in the framework of supervision, and provide a substantial percentage of mining area rights and mining activities for local communities, by initiating to reconstruct mining laws related to people's mining rights and activities, and also related to foreign parties can not be too open and only in coordination with the government but the central government should be involved despite the regional autonomy, but we must look at Article 33 of the Constitution of 1945, after which the income from mining activities must be allocated as much as possible for development and miles from the local people.

\section{REFERENCES}

[1] S. F. Sembiring, New Road to Mine: Flowing Blessing for Children of the Nation. Jakarta: Elex Media Komputindo, 2009.

[2] B. Azeri, Principles of Mineral and Coal Management, vol. 4. Jakarta: Raja Grafinfo Persada, 2008.

[3] A. deputy for E. I. Assessment, Question and Answer. Ministry of Environment, 2006

[4] "Center for the Development and Implementation of AMDAL and BAPEDAL."

[5] A. Budiman, Theory Country: State, Power and Ideology. Jakarta: Gramedia, 1996.

[6] S. A. Keraf, Business Ethics: Demands and Relevance. Yogyakarta: Kanisius, 1998.

[7] L. . Van Apeldoom, "Inleiding tot de studie van het Nederlandse Recht, terjemahan oleh Oetarid Sadino," in Pengantar Ilmu Hukum, Jakarta: Pradya Paramita, 1980.

\section{REGULATION.}

1945 Constitution

Law No. 4 of 2009 on Minerals and Coal

Law Number 23 Year 2014 on Regional Government 